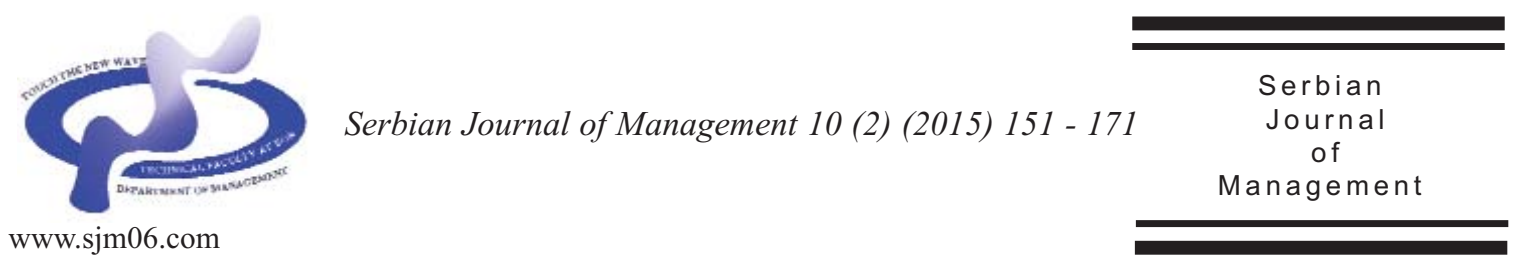

\title{
MODIFICATION OF THE ANALYTIC HIERARCHY PROCESS (AHP) METHOD USING FUZZY LOGIC: FUZZY AHP APPROACH AS A SUPPORT TO THE DECISION MAKING PROCESS CONCERNING ENGAGEMENT OF THE GROUP FOR ADDITIONAL HINDERING
}

\author{
Darko Božanić, Dragan Pamučar and Dragan Bojanić* \\ Military Academy, University of Defence in Belgrade, \\ Generala Pavla Jurišića Šturma 33, 11000 Belgrade, Serbia
}

(Received 30 November 2014; accepted 30 March 2015)

\begin{abstract}
This paper presents the modification of the AHP method, which takes into account the degree of suspense of decision maker, that is it allows that decision maker, with a certain degree of conviction (which is usually less than $100 \%$ ), defines which linguistic expression corresponds to optimality criteria comparison. To determine the criteria weights and alternative values, fuzzy numbers are used since they are very suitable for the expression of vagueness and uncertainty. In this way, after applying the AHP method, we obtained values of criterion functions for each of the examined alternatives, which corresponds to the value determined by the degree of conviction. This provides that for different values of the degree of conviction can be made generation of different sets of criterion functions values. The set model was tested on choosing directions of action of the Group for additional hindering, as a procedure wich is often accompanied by greater or lesser degree of uncertainty of criteria that are necessary in relevant decision making.
\end{abstract}

Keywords: Fuzzy algebras, fuzzy AHP, AHP method, the additional hindering group, the direction of action

\section{INTRODUCTION}

Making complex decisions must be viewed as a complex process. It takes place at several levels and generally has a variable schedule depending on the overall scenario, that is decision-making environment. For example, at the creative level, professional skills and psychological background of decision makers are very important. At the executive level essential are willingness to reflect, ability of consistent reasoning and level of operational capability of a person to make decisions based on their own intuition.

\footnotetext{
* Corresponding author: draganbojanic@yahoo.com

DOI:10.5937/sjm10-7223
} 
At the level of responsibility it is very important the level of awareness of decision makers that decision making process is a responsible act, as well as that the decision making process and decisions rising from it contain morality and understanding of consequences of decisions implementation.

In addition, it should be emphasized that the decision making is psychologically complex and laborious process. It usually contains a multitude of interrelated and mutually dependent factors whose impact is not simple to identify accurately (consistently) and link in the whole of the outcome (decision). In this regard, many authors of scientific papers, and practitioners (the actual decision makers), indicate that optimal decisions are not usually made based on personal reflection or intuition. This increasingly points the necessity of using scientifically based methods in decision making process.

Since the theory of fuzzy sets (Zadeh, 1965) was proposed in 1965, it has been used for handling fuzzy decision-making problems (Chen, 2000; Hong \& Choi, 2014; Jae \& Moon, 2002; Fan \& Liu, 2015). Kickert (1978) has discussed the field of fuzzy multi-criteria decision-making. Zimmermann (1987) illustrated a fuzzy set approach to multi-objective decisionmaking, and he has compared some approaches to solve multi-attribute decisionmaking problems based on fuzzy set theory. Yager (1978) presented a fuzzy multiattribute decision-making method that uses crisp weights. Yager (1988) introduced an ordered weighted aggregation operator and investigated its properties. Laarhoven and Pedrycz (2003) presented a method for multi-attribute decision making using fuzzy numbers as weights.

Vague sets, which Gau and Buehrer
(2013) presented, are a generalized form of fuzzy sets. These sets were used by Chen and Tan (2014). They presented some new techniques for handling multi-criteria fuzzy decision-making problems based on vague set theory, where the characteristics of the alternatives are represented by vague sets. The proposed techniques used a score function, $\mathrm{S}$, to evaluate the degree of suitability to which an alternative satisfies the decision-maker's requirement. Recently, Hong and Choi (2014) proposed an accuracy function, $\mathrm{H}$, to measure the degree of accuracy in the grades of membership of each alternative, with respect to a set of criteria represented by vague values. However, in some cases, these functions do not give sufficient information about alternatives.

Chen and Tan (2014), Hong and Choi (2014), Liu and Wang (2007) and Ye (2010, 2014) presented some new techniques for handling fuzzy multi-criteria decisionmaking problems based on vague set theory or intuitionistic fuzzy sets, where the characteristics of the alternatives are represented by vague sets or intuitionistic fuzzy sets and the criteria weights are given by fuzzy numbers. However, intuitionistic fuzzy sets is the same as fuzzy sets, the domains of which are discrete sets, intuitionistic fuzzy sets are used to indicate the extent to which the criterion does or does not belong to some fuzzy concepts. The notion of a fuzzy number and the operation on fuzzy numbers were introduced by Dubois and Prade (1978, 1987). Nehi and Maleki (2005) proposed Intuitionistic trapezoidal fuzzy numbers and some operators for them, which are the extending of intuitionistic triangular fuzzy numbers. Intuitionistic triangular fuzzy numbers and intuitionistic trapezoidal fuzzy numbers are 
the extending of intuitionistic fuzzy sets in another way, which extends discrete set to continuous set, and they are the extending of fuzzy numbers.

Furthermore, the expected value method is also applied to ranking. Heilpern (1992) proposed the expected value of a fuzzy number. Then Grzegrorzewski (2013) proposed the expected value and ordering method for intuitionistic fuzzy numbers by using the expected interval of intuitionistic fuzzy numbers. Also Wang and Zhang (2014) defined some aggregation operators, including intuitionistic trapezoidal fuzzy weighted arithmetic averaging operator and weighted geometric averaging operator, and proposed an intuitionistic trapezoidal fuzzy multi-criteria decision-making method with known weights based on expected values, score function, and accuracy function of intuitionistic trapezoidal fuzzy numbers.

Fuzzy multi-criteria evaluation methods are used widely in fields such as information project selection, material selection and many other areas of management decision problems (Chen, 2000; Chen \& Tzeng, 2014; Yeh \& Deng, 2014) and strategy selection problems (Chiadamrong, 2013; Ding \& Liang, 2015).

Li (1999) proposed a simple and efficient fuzzy model for dealing multi-judges and multi-criteria decision making problems in fuzzy environment and suggested a level weighted fuzzy relation for comparing or ranking sets. This method can avoid an immediately defuzzified process when it can provide a precise solution. In addition, the technique of ideal and anti-ideal points is used easily to find the best alternative, considering that the chosen alternative should simultaneously have the shortest distance from the positive ideal point and the longest distance from the negative ideal point (Anagnostopoulos et al., 2008; Chen \& Tzeng, 2014; Kuo et al., 2007). The ideal point is composed of all best criteria available and the anti-ideal point is composed of all worst criteria attainable. Several extensions of TOPSIS have been made to incorporate fuzzy numbers in the process. Chen (2000), in order to solve a group decision-making problem, measured the distance between two trapezoidal fuzzy numbers by a vertex method resulting in a crisp distance value and used the ideal and anti-ideal solutions to define a crisp overall score for each alternative.

Chang and Yeh (2012) as well as Xu et al. (2010) proposed a multi-criteria method based on the similarity of each alternative to the ideal and anti-ideal solutions and they used fuzzy similarity measure instead of distances. Kuo et al. (2007) proposed a method combining the efficient fuzzy model (Li, 1999) and the principles of TOPSIS to solve multi-criteria in a fuzzy environment. This method results in fuzzy distance values which are compared by a fuzzy ranking method. Further, grey relations and pairwise comparison, to obtain preference relations and ranking order of the alternatives, are combined to create a fuzzy method by Kuo et al. (2007).

The technique often used in the field of multi-criteria decision making is the Analytic Hierarchy Process (Saaty, 1980). It is based on the decomposition of a complex problem into a hierarchy, with the goal at the top, and criteria, sub criteria and alternatives at the levels and sub-levels of hierarchy. The decision maker makes comparison of elements in pairs at each level of hierarchy in relation to the elements at a higher level by using some of the preferred scales, usually so-called Saaty's scales. The end result are the vectors of relative importance (priorities) 
of alternatives in relation to the goal.

Analytic Hierarchy Process (AHP) is a method of scientific analysis of scenario and decision making using consistent valuation of hierarchies. AHP has been applied in various fields of strategic management and resource allocation, where decisions have far-reaching importance and where the decision makers need quality and reliable advice during alternatives consideration and determination of their effects in relation to the set objectives. The scientific capacity of AHP is proved by a number of dissertations at prestigious international universities and many research papers at scientific conferences and journals (Saaty, 1996; Ray \& Triantaphyllou, 1999; Raju \& Pillai, 1999; Arslan \& Khisty, 2006; Boender et al.,1989; Chang, 1981; Chen, 1997; Zhu et al., 1999; Devetak \& Terzić, 2011).

AHP method has been intensively used in decision-making processes in a military environment, especially in decision-making in combat operations. The application of AHP methods in support of decision making for choosing courses of action of the Group for additional hindering (GAH), will be shown through this work.

GAH is a temporary engineering structure that is generally organized in defense operations with the basic task to hider directions of sudden invasion of opponents (especially their armored and mechanized units). They act independently or with other elements of the antiarmored combat in the directions (usually additional) where there are not organized positions for antiarmor combat, in the interstices, on the exposed sides, in the direction of stronger expansion of air-raids and similar (Military Lexicon, 1981). It is equipped with a number of antitank mines, minelayer, and depending on need it is assigned other light antitank means, means of transport and mines and explosive means (Military Lexicon, 1981). One GAH is generaly determined with the starting point, one of two lines of action, and in every direction of action two or three lines of hidering (Military Lexicon, 1981). The Starting point and lines of hindering are primarily conditioned by the defined directions of action of this group. In essence, defining lines of action of the GAH is the basis for assigning specific tasks for it.

In order to have GAH properly used and to achieve maximum performance it is necessary that the person who decides, makes the selection of GAH direction of action on which it will be most effectively used. Usually, in practice, a number of offered directions are imposed, and the person who decides chooses one or two.

\section{METHODOLOGY}

\subsection{Fuzzy logic}

Fuzzy sets were introduced with the basic goal that the uncertainty in linguistics is represented and modeled in a mathematically formalized way, and sets defined this way can be perceived as a generalization of classical set theory. The basic idea of fuzzy sets is very simple. In the classical (nonfuzzy) sets an element (a member of the universal set), either belongs or does not belong to defined set. In this sense, fuzzy set is a generalization of classical set as the membership of an element can be characterized by a number from interval $[0,1]$. In other words, the membership function of fuzzy set maps each element of the universal set in this interval of real numbers. One of the biggest differences between classical and fuzzy sets is in the fact 
that classical sets always have a unique membership function, while for the fuzzy set there is an infinite number of different membership functions which can describe it. This fact allows fuzzy systems to adapt appropriately to situations where applicable. This fact was pointed by Lotfi Zadeh (1965) who defined fuzzy sets, with a special note that each area can be fuzzicated and therefore it can generalize until then conventional classical approach to the sets theory.

\section{The concept of fuzzy number}

In determining time required to perform tasks in the Serbian Armed Forces' units very often it can be heard estimation that a task can be done for "about a couple of minutes." This means that, for example, "about three minutes" is the nearest integer which in best way expresses the approximate value of the time necessary to perform the task.

The statement that the time required to perform the task is three minutes we will interpret equally in any situation. However, when we say that the time required to perform an activity is nearly three minutes we can ask ourselves: "How close?", "What is the maximum error?", and sometimes it is a sufficient information to us. If we say that the time required to perform activity is "about three", on the one hand it might be sufficient information to us, and on the other hand it may only increase the confusion.
Similar descriptions of situations one successfully uses in decision making process, and fuzzy logic allows us to use such, seemingly imprecise, information in many scientific fields. Figure 1 illustrates this idea, that is to apply, instead of precise and rigorous descriptions of complex phenomena, the opposite approach and allow them to be inaccurate (Pamučar, 2010).

\section{The term of fuzzy set}

The classical discrete set is a set of elements with the same properties. Each element of a discrete set belongs to it $100 \%$, or on a scale of zero to one, we can say that each element of a discrete set belongs to that set with the degree of 1 . Of course, the discrete element may not be the part of the set, then we can say that it belongs to the set with the degree of 0 .

Fuzzy set is an extension and generalisation of the classical discrete set (Jantzen, 1998). It represents a set of elements with similar properties. The degree of element membership in a fuzzy set can be any real number from the interval.

Definition (Teodorović \& Kikuchi, 1994): Fuzzy set $A$ on the non-empty set $U$ is called the ordered pair $\left(\mu_{A}(x), x\right)$, where $\mu_{A}(x)$ is the degree of membership of element $x \in U$ in fuzzy set $A$. The degree of membership is a number from the interval $[0,1]$. The membership degree bigger, the element of the universal set $U$ correspond to a greater

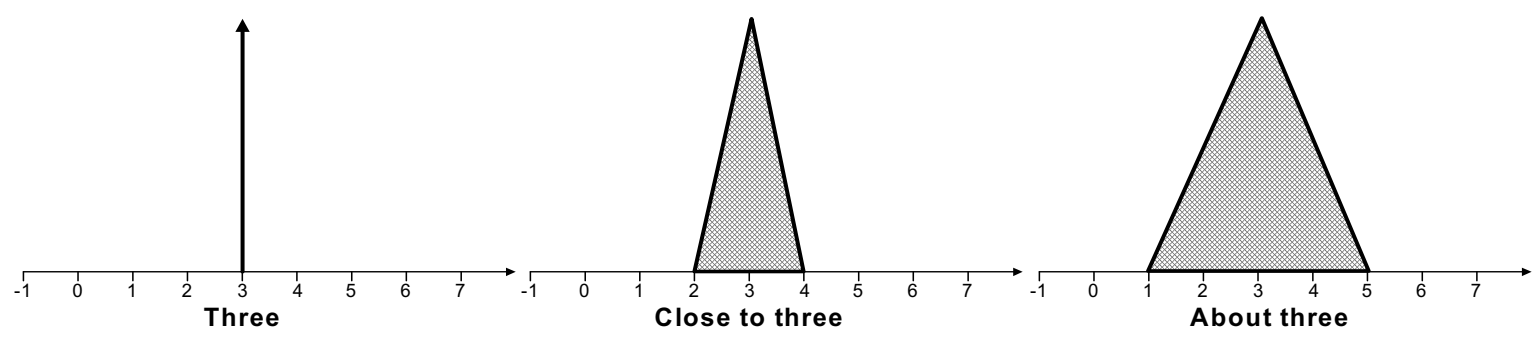

Figure 1. Fuzzy number 
extent to the characteristics of a fuzzy set.

Formally, the fuzzy set $A$ is defined as a set of ordered pairs

$A=\left\{\left(x, \mu_{A}(x)\right) \mid x \in X, 0 \leq \mu_{A}(x) \leq 1\right\}$

If we define the reference set $V=\{o, p, r$, $s, t\}$, a fuzzy set could look like this $B=$ $\{(0.3, o),(0.1, p),(0, r),(0, s),(0.9, t)\}$. This means that the element $o$ belongs to the set $B$ with degree $0.3, p$ with degree $0.1, t$ with degree 0.9 , and $r$ and $s$ do not belong to the set $B$ (Pamučar, 2010).

\section{Membership functions}

Each fuzzy set can be represented by its membership function. If the reference set is discrete, membership function is a set of discrete values from the interval $[0,1]$, as in the previous example. If the reference set is continuous, it can be expressed analytically by using membership function.

The most commonly used forms of membership functions are (Pamučar et al., 2011a):
- Triangular functions, Figure 2c,

- Trapezoidal functions, Figure 2a,

- Gaussian curve, Figure 2d, and

- Bell curve Figure 2b.

In the figure 2. the ordinate represents the degree of membership. The fuzzy variable $x$ is shown on the abscissa.

Mathematical expressions describing the membership functions shown in Figure 2. have the following form:

$$
\begin{aligned}
& \mu_{c}(x)=\left\{\begin{array}{cc}
0, & 0<x<a \\
(x-a) /(c-a), & a \leq x \leq c \\
(e-x) /(e-c), & c \leq x \leq e \\
0, & x>e
\end{array}\right\} \\
& \mu_{a}(x)=\left\{\begin{array}{cc}
0, & 0<x<a \\
(x-a) /(b-a), & a \leq x \leq b \\
1, & b \leq x \leq d \\
(e-x) /(e-c), & d \leq x \leq e \\
0, & x>e
\end{array}\right\} \\
& \mu_{d}(x)=e^{-\frac{1}{2}\left(\frac{x-c}{e}\right)^{2}}
\end{aligned}
$$

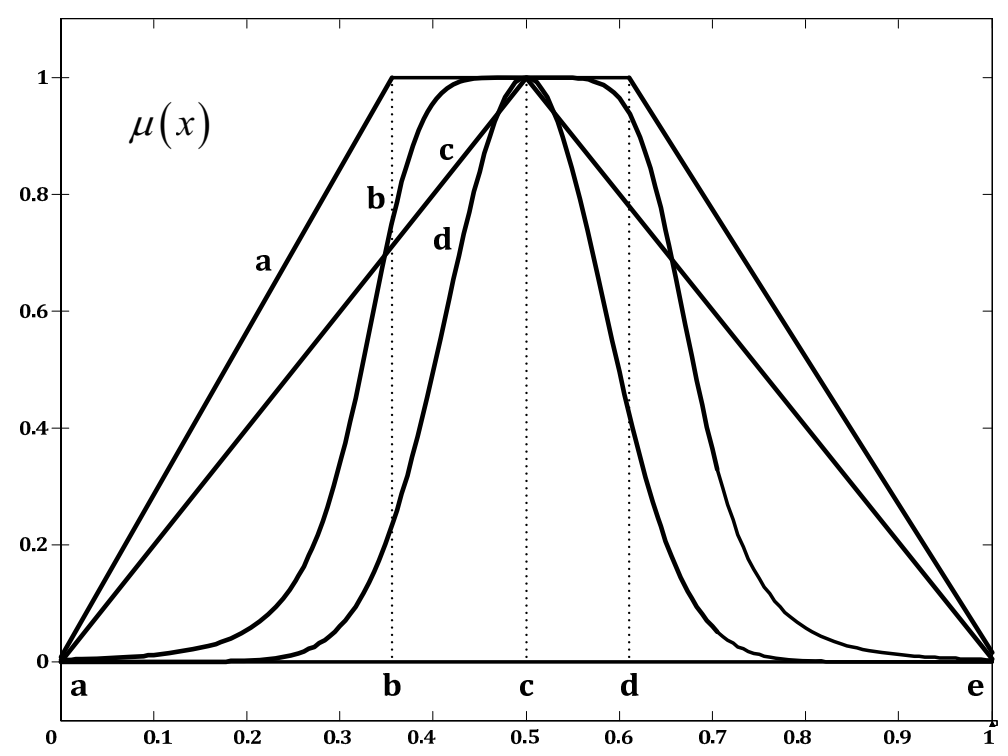

Figure 2. The most commonly used forms of membership functions 
$\mu_{b}(x)=\frac{1}{1+(x-c)^{2}}$

Most tools for designing fuzzy systems allow the user to define different random membership functions (Pamučar, 2010).

\section{Universe of discourse}

The elements of fuzzy sets are taken from the universe of discourse. The universe of discourse contains all the elements that can be taken into consideration. It means that fuzzy variable can take values only from the universe of discourse.

Clarifying the concept of universe of discourse will be observed through the variable time required to perform the task. In terms of time required to perform the task there is a high degree of uncertainty, but we are assured that this time will not be longer than $t_{2}$ or less than $t_{1}$. In other words, we are assured that time belongs to the closed interval $\left[t_{1}, t_{2}\right]$. This closed interval is called the universe of discourse and it is simbolicaly marked as $T=\left[t_{1}, t_{2}\right]$, Figure 3 .

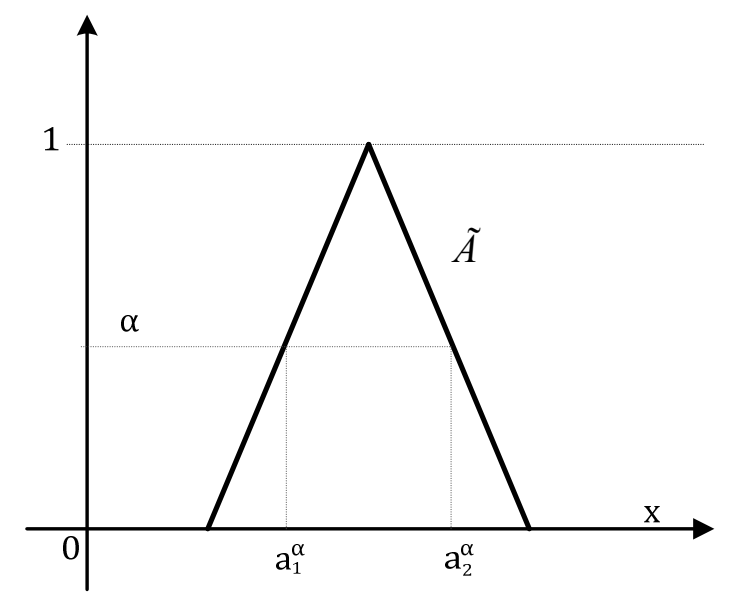

Figure 3. Fuzzy $\tilde{A}$ number with the corresponding universe of discourse and degree of conviction
Determination of the universe of discourse of each fuzzy variable is the task of the designer and the most natural solution is to adopt the universe of discourse so that it matches the physical boundaries of the variable. If the variable is not of a physical origin, one of the standard universes of discourse is adopted or an abstract universe of discourse is defined (Božanić \& Pamučar, 2010; Pamučar et al., 2011b).

In addition to the universe of discourse, the triangular fuzzy number, in our case fuzzy time, is characterized by the degree of conviction. The concept based on which the fuzzy number is expressed using universe of discourse and corresponding degrees of conviction is suggested by Kaufmann and Gupta (1985). Figure 3 shows the fuzzy number $\tilde{A}$. The universe of discourse which corresponds to the degree of conviction $\alpha$ is marked as $\left[a_{1}^{\alpha}, a_{2}^{\alpha}\right]$.

\subsection{The methodological basis of AHP}

The analytic hierarchy process belongs to the class of methods for soft optimization. Basically, this is a specific tool for the analysis of hierarchically arranged elements of decision making. AHP method performs the previous analysis and decomposition of the evaluation problem in pairs of hierarchy elements (goals, criteria and alternatives), mostly in the "top-down" direction, and although it may be reversed or combined. At the end, all evaluations are sintetized and according to the established mathematical model they determine weighted values of the hierarchy elements. Since the sum of the weighed values of the elements at each hierarchy level is 1 , the decision maker can rank all elements of decision making in the horizontal and vertical sense.

AHP allows interactive analysis of the 
sensitivity of the evaluation process at the final ranks of the hierarchy of elements. Additional feature of the method is that during the evaluation of elements of the hierarchy, until the end of the synthesis procedure and the results, the consistency of decision maker reasoning can be verified in order to monitor the correctness of the obtained weight values and rankings of alternatives and criteria.

Methodologically speaking, AHP is a technique based on the decomposition of a complex problem into a hierarchy where the goal is at the top of the hierarchy, and the criteria, subcriteria and alternatives are at lower levels. As an illustration, figure 4 shows the hierarchy consisting of the goal, eight criteria and four alternatives. The hierarchy does not have to be complete, eg. an element at some level does not have to be a criterion for all elements in the sub-level, so that the hierarchy can be divided into subhierarchies, whose only common element is at the top of the hierarchy.

AHP is a flexible method that allows complex problems with many criteria and alternatives to relatively easily find a relationship between the influencing factors, recognize their relative influence and importance in practical applications and determine the dominance of one factor over another. The method anticipates the fact that even the most complex problem can be broken down into a hierarchy. AHP holds all parts of the hierarchy in an order, so that it is easy to see how changes of one factor affect the other factors. In essence, the method does not insist on the differences between quantitative and / or qualitative criteria, or possible differences in the matrix of quantitative criteria.

In addition to the hierarchical structuring of the problem, the AHP methodology differs from other multicriteria methods because it performs comparison in pairs of elements $E 1, E 2, \ldots, E n$ at a given level of hierarchy in relation to the elements at a higher level. Each element at the higher level needs n(n1) $/ 2$ comparisons of semantic or numeric type as defined by Saaty's scale in table 1 .

Table 1. Saaty's scale for comparison in pairs

\begin{tabular}{cl}
\hline Standard values & Definition \\
\hline 1 & Equal significance \\
3 & Low dominance \\
5 & High dominance \\
7 & Highly dominance \\
9 & Apsolut dominance \\
$2,4,6,8$ & Average values \\
\hline
\end{tabular}

$$
S=\left\{\frac{1}{9}, \frac{1}{8}, \frac{1}{7}, \frac{1}{6}, \frac{1}{5}, \frac{1}{4}, \frac{1}{3}, \frac{1}{2}, 1,2,3,4,5,6,7,8,9\right\}
$$

Looking from the top of the hierarchy, the goal is at the top and it does not compare

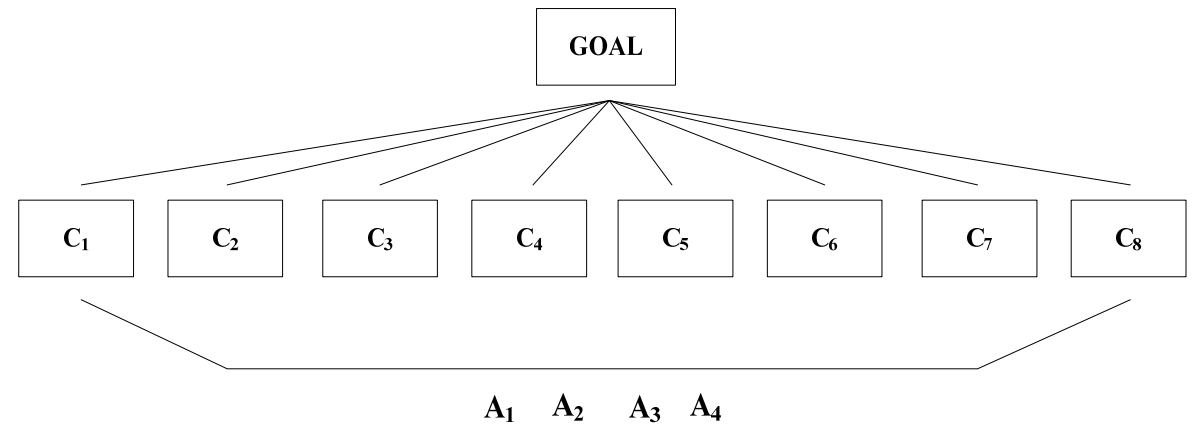

Figure 4. An example of the hierarchical structure of the problem in the AHP method 
with any of the other elements. At the level 1 there are the criteria which are compared in pairs, each to each, with respect to the immediate parent element at a higher level (the goal here is at the zero level). The procedure is applied by going down through the hierarchy, until at the last level $\mathrm{k}$ there are not performed comparisons of all alternatives with respect to the parent subsub-... sub-criteria at the penultimate (k-1) level, figure 5. infinite set of possibilities, for example, one finds it difficult to distinguish values such as 5.00 and 5.09. Since the psychological experiments have shown that one can not simultaneously compare more than seven objects (plus or minus 2) (Miller, 1956), Saaty defined the scale that has the highest value 9, the lowest value 1 and the difference between the notches 1. Saaty scale is generally considered a standard for AHP, and it is used for comparison in pairs. According

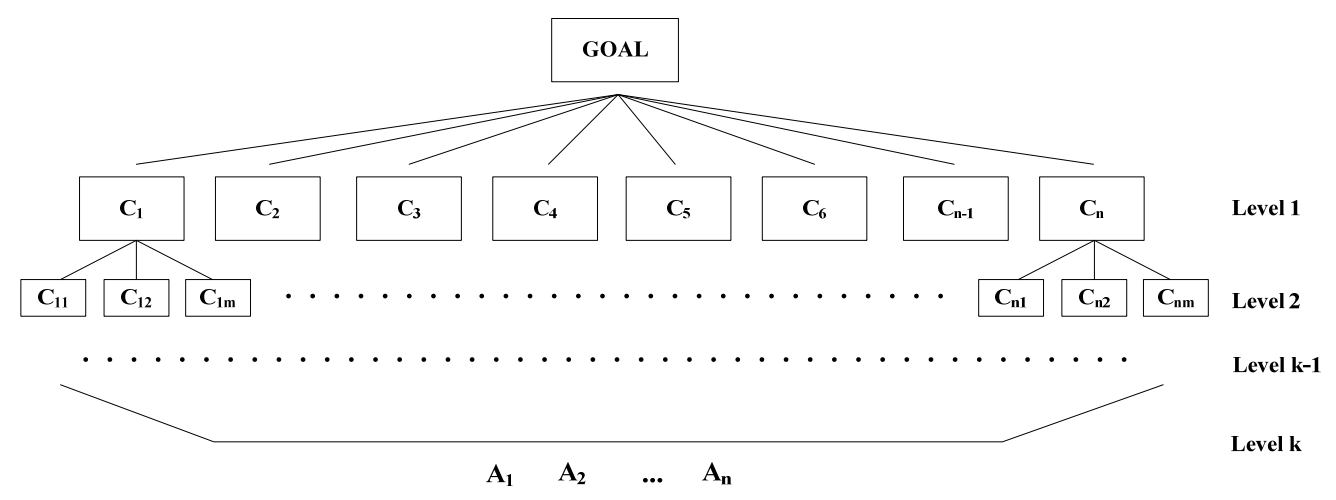

Figure 5. The general hierarchical model in AHP

The main problem with the comparisons in pairs is how to quantify the linguisticaly formulated selections - the phrases. In most methods that use comparisons it is achieved by using the appropriate numerical values, usually expressed by fractions with whole numbers. When by comparision one wants to express the similarity, rather than the relative ratio, instead of fractions there can be used differences of integers (Triantaphyllou \& Lin, 1996). In developing the scale of evaluation, there are two approaches: linear (Saaty, 1990) and exponential (Lootsma, 1988; Boender et al., 1989; Lootsma et al., 1990). Both approaches are based on certain theories from the field of psychology, and here only the first one is of interest which by far dominates in the application.

It is believed that people are generally not able to conduct selections if they have the to this scale, which will be called for easy identification Scale 1, the available values for the comparison in pairs are the elements of a discrete set of 17 values.

Scale $1=$ Saaty's scale $=\{9,8,7,6,5,4$, $3,2,1,1 / 2,1 / 3,1 / 4,1 / 5,1 / 6,1 / 7,1 / 8,1 / 9\}$.

Elements symmetric with respect to 1 are reciprocal. Values from Scale 1 can be grouped into two intervals: $[1,9]$ and $[1 / 9$, 1]. As shown above, the values in the interval $[1,9]$ are uniformly distributed, while the values in the interval $[1 / 9,1]$ are grouped on the right side of the interval. There is no good reason that for the defined scale in the interval [1,9] the values are properly distributed. An alternative could be that the values in the interval $[1 / 9,1]$ are properly distributed, and that other values are their 
reciprocal values. Ma and Zeng (1991) have matrix of comparisons.

suggested the scale of this kind (Scale 2).

Scale $2=$ Ma and Zeng's scale $=\{9,9 / 2$,

$$
A=\left\{a_{i j}\right\} \in R_{n x n}
$$

9/3, 9/4, 9/5, 9/6, 9/7, 9/8,1, 8/9, 7/9, 6/9, 5/9 $4 / 9,3 / 9,2 / 9,1 / 9\}$.

As is true $a_{\mathrm{ji}}=1 / a_{\mathrm{ij}}$ and $a_{\mathrm{ii}}=1$ for each $i$, $j=1,2, \ldots, n$, the matrix $\mathrm{A}$ is positive, balanced and reciprocal. The essential

In the interval $[1 / 9,1]$, the interval between successive values is $(1-1 / 9) / 8=$ $1 / 9$, so that the values are properly distributed. The values in the interval $[1,9]$ are the reciprocal values from the interval $[1 / 9,1]$.

Similar to Scale 2 the other, for example weighing values from the previous scales may be defined. For the interval $[1 / 9,1]$ values can be computed using the formula:

$\mathrm{NV}=\mathrm{V}($ Scale 1$)+[\mathrm{V}($ Scale 2$)-\mathrm{V}($ Scale $1)]^{*}(\alpha / 100)$

where labels $\mathrm{NV}$ and $\mathrm{V}$ mean the new value and value, respectively, a parameter $\alpha$ may vary from 0 to 100 . The values in the interval $[1,9]$ are reciprocal values for the values calculated by the top form. For $\alpha=0$ is obtained Scale 1, and for $\alpha=100$ is obtained the Scale 2.

Previous analyzes have shown that does not exist a scale that is the most applicable for all situations, nor it can be said that there is the non-applicable scale (Triantaphyllou et al., 1998).

The Saaty's scale from table 1 is dominant in applications even though it has certain disadvantages. One of the disadvantages is that the half of the scale is linear, and the other half is non-linear. This means that when a decision maker or analyst performs comparisons in pairs, based on semantic preferences from the right column (table 1) or by direct association, a number of values in the left column are put in the square information about preferences of elements $E_{1}, E_{2}, \ldots, E_{\mathrm{n}}$ can be found only in the upper triangle of the matrix, but all the procedures for its further analysis use the reciprocal values of the lower triangle.

The main disadvantage of such approaches is the "non-flexible" definition of the intensity of the importance of linguistic expressions, which can be solved by the fuzzification of linguistic expressions. The fuzzification of Saaty's scale is described in many papers (Chang, 1981; Boender et al.,1989; Chen, 1997; Zhu et al., 1999; Arslan \& Khisty, 2006; Devetak \& Terzić, 2011; Pamučar et al., 2011c, 2012, 2015; Božanić et al., 2013).

Common to all these approaches is "sharp" fuzzification of linguistic expressions in the Saaty's scale which are presented whit triangular fuzzy numbers. By the "sharp" fuzzification we mean that for the fuzzy number $T=\left(t^{1}, t_{2}, t_{3}\right)$ the universe of discourse is determined ahead i.e. it is defined ahead that the value of the fuzzy number will not be greater than $t_{3}$ or less than $t_{1}$. In other words, we are confident that the value of linguistic expressions belongs to a closed interval $\left[t_{1}, t_{3}\right]$.

In the papers (Pamučar et al., 2011c, 2012, 2015; Božanić et al., 2011, 2013), the modification-Saaty's scale was used, and it was also used in this study. During Fuzzification of the Saaty's scale, triangular fuzzy numbers were used. Unlike the previously mentioned papers in which the 
process of the Fuzzification of the AHP/ANP methods was described, the degree of uncertainty of the decision-makers has been taken into account in the model applied in this paper. In this way, after the application of AHP / ANP method, the values of criterion functions for each of the considered alternatives which corresponds to the value determined by the degree of certainty are obtained. Advantages of the scale fuzzyficated in this way are abilities to generate different criteria functions for different values of the degree of certainty.

The model presented in this study takes into account the degree of uncertainty marked with the parameter $\beta$. In doing so, the value of $\beta=0$ describes the maximum possible uncertainty, while the value of $\beta=1$ corresponds to a situation where we know with absolute certainty what linguistic expression corresponds to a given comparison of the optimality criterion. The value of the parameter $\beta$ can be any number in the interval $[0,1]$. Using the described procedure the fuzzification of Saaty's scale was performed as shown in table 1 .

In this way, for the set value of parameter $\beta$, we choose lower and upper limit of the universe of discourse fuzzy number randomly, so that they are within the limits defined by the following expression:

$$
T=\left(t_{1}, t_{2}, t_{3}\right)=\left\{\begin{array}{lr}
t_{1}=\beta t_{2}, & t_{1} \leq t_{2}, \\
t_{2}=t_{2}, & t_{1}, t_{2} \in[1 / 9,9] \\
t_{3}=(2-\beta) t_{2}, & t_{3} \leq t_{2}, \quad t_{2}, t_{3} \in[1 / 9,9]
\end{array}\right\} \text { (8) }
$$

where the value $t_{2}$ is the value of linguistic expression where membership function has the maximum value, i.e. $t_{2}=1$.

After fuzzification of the Saaty's scale, table 2., the process of implementation of AHP method is the same as in the classical AHP method.

A detailed description of the phases of AHP method is shown in the literature (Lootsma, 1988; Kujačić, 2001). Defuzzification of fuzzy numbers is done using the method of Centre of gravity according to the expression:

Table 2. Fuzzy Saaty's scale for comparison in pairs

\begin{tabular}{|c|c|c|}
\hline \multirow{2}{*}{ Definition } & \multicolumn{2}{|c|}{ Fazzy values } \\
\hline & Fuzzy number & Inverse fuzzy number \\
\hline $\begin{array}{l}\text { Equal } \\
\text { significance }\end{array}$ & $\begin{array}{l}(1,1,1) \text { If the comparison is with } \\
\text { itself, } \\
\left(t_{1}, x, t_{2}\right) \text { in other cases }\end{array}$ & $\begin{array}{l}(1 /(2-\beta), 1 / x, 1 / \beta) \\
\text { in other cases }\end{array}$ \\
\hline Low dominance & $\left(t_{1}, 3, t_{2}\right)$ & $\left(1 / t_{2}, 1 / 3,1 / t_{1}\right)$ \\
\hline High dominance & $\left(t_{1}, 5, t_{2}\right)$ & $\left(1 / t_{2}, 1 / 5,1 / t_{1}\right)$ \\
\hline $\begin{array}{l}\text { Highly } \\
\text { dominance }\end{array}$ & $\left(t_{1}, 7, t_{2}\right)$ & $\left(1 / t_{2}, 1 / 7,1 / t_{1}\right)$ \\
\hline $\begin{array}{l}\text { Absolute } \\
\text { dominance }\end{array}$ & $\left(t_{1}, 9, t_{2}\right)$ & $\left(1 / t_{2}, 1 / 9,1 / t_{1}\right)$ \\
\hline Medium values & $\begin{array}{l}\left(t_{1}, x, t_{2}\right) \\
x=2,4,6,8\end{array}$ & $\begin{array}{l}\left(1 / t_{2}, 1 / x, 1 / t_{1}\right) \\
x=2,4,6,8\end{array}$ \\
\hline
\end{tabular}


defuzzy $T=\left[\left(t_{3}-t_{1}\right)+\left(t_{2}-t_{1}\right)\right] \square 3^{-1}+t_{1}$

In this way, after the application of AHP method, the values of criteria functions for each of the studied alternatives are given. The obtained values of criteria functions correspond to a certain parameter value $\beta$. For different values of parameter $\beta$ it is possible to generate different sets of values of criteria functions. In the paper there will be generated five sets of values of criteria functions for three different values of the parameter $\beta, \beta=0, \beta=0.5$ and $\beta=1$. Thus, for the different degrees of conviction of a decision maker we get different appearance of the scale.

\subsection{Consistency of matrices in fuzzy AHP method}

Fuzzy AHP makes it possible to identify and analyze inconsistency of decision maker in the process of reasoning and evaluation of the hierarchy elements. One is rarely consistent in estimating the values or the relationship of quantitative and qualitative elements in the hierarchy. Fuzzy AHP in a certain way recognizes this fact in the way it has an approximate mechanism for measuring the consistency which is based on certain premises and simple matrix operations.

When one had the ability to accurately determine the values of weight coefficients of all elements which are mutually comparable at a given level of hierarchy, the values of the matrix itself would be completely consistent. However, if it is claimed that $\mathrm{A}$ is much more important than $\mathrm{B}, \mathrm{B}$ a little bit more important than $\mathrm{C}, \mathrm{C}$ a little bit more important than $\mathrm{A}$, that results in inconsistency in solving problems and in reducing the reliability of results. The general view is that redundancy of comparisons in pairs makes AHP the method that is not too sensitive to errors in reasoning. It also provides the ability to measure errors in reasoning by calculating an index of consistency for the resulting matrix of comparisons, and then calculates the degree of consistency.

In order to calculate the degree of consistency, we should first calculate the index of consistency according to the relation:

$$
C I=\frac{\lambda_{\max }-n}{n-1}
$$

where the $\lambda_{\max }$ is a maximum net value of the comparison matrix. The $\lambda_{\max }$ closer to the number $n$, the inconsistency is smaller.

In order to calculate $\lambda_{\text {max }}$, first the matrix of comparisons should be multiplied with the vector of weight coefficients to determine the vector $b$.

$$
\left[\begin{array}{ccccc}
a_{11} & a_{12} & \cdot & \cdot & a_{1 n} \\
a_{21} & a_{22} & \cdot & \cdot & a_{2 n} \\
\cdot & & & & \cdot \\
\cdot & & & & \cdot \\
a_{n 1} & a_{n 2} & \cdot & \cdot & a_{n n}
\end{array}\right]\left[\begin{array}{c}
w_{1} \\
w_{2} \\
\cdot \\
\cdot \\
w_{n}
\end{array}\right]=\left[\begin{array}{c}
b_{1} \\
b_{2} \\
\cdot \\
\cdot \\
b_{n}
\end{array}\right]
$$

Dividing the corresponding elements of vector $\mathrm{b}$ and $\mathrm{w}$ if is obtained $\lambda_{\max }$.

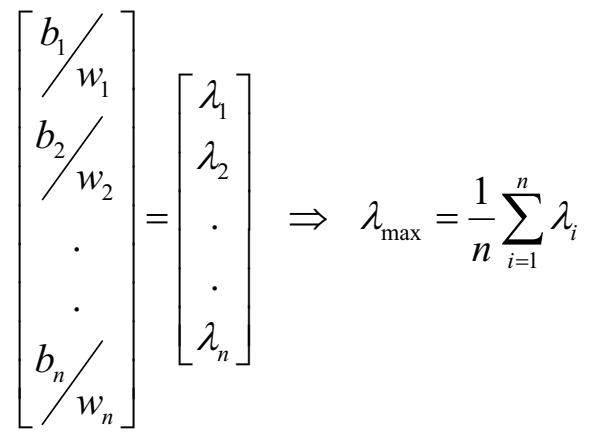

The degree of consistency $(C R)$ is the 
ratio of consistency index $(C I)$ and random situation to rank a number of proposed index $(R I)$.

$C R=\frac{C I}{R I}$

Random index $(R I)$ depends on the order of the matrix, and it is taken from table 3 where the first row is the row of matrix of comparison, and the second row is the row of random indexes (Saaty, 1980; Peneva \& Popchev, 1998). locations and conclude which one is the best to be chosen. Ranking locations is performed by evaluation of each location with the aim of selecting the best out of the set of proposed options, in relation to the importance of the chosen criteria. If there is a possibility of changes, the number of options is larger, thus the optimization of selection is more complex (Pamučar et al., 2011a, 2011b).

Table 3. Random index

\begin{tabular}{|c|c|c|c|c|c|c|c|c|c|c|c|c|c|c|}
\hline 1 & 2 & 3 & 4 & 5 & 6 & 7 & 8 & 9 & 10 & 11 & 12 & 13 & 14 & 15 \\
\hline$\stackrel{\ominus}{\theta}$ & $\stackrel{\ominus}{\circ}$ & 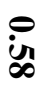 & 8 & $\dot{\vec{N}}$ & $\vec{i}$ & i & $\dot{\dot{\oplus}}$ & $\overrightarrow{\dot{\theta}}$ & $\vec{t}$ & in & $\overrightarrow{\dot{\infty}}$ & $\overline{\check{z}}$ & $\vec{y}$ & $\overline{\text { ing }}$ \\
\hline
\end{tabular}

If the degree of consistency $(C R)$ is less than 0.10 , the result is sufficiently accurate and there is no need for adjustments in the comparisons and repeating the calculation. If the degree of consistency is greater than this value, one should determine the reasons for inconsistency, remove them by partial repetition of the comparison in pairs, and if repeated procedure in several steps doesen't lead to a reduction of the degree of consistency to tolerable limits, all results should be discarded and the whole process should be repeated from the very start.

\section{RESULTS AND DISCUSSIONS}

\subsection{Defining criteria for selection of action directions of GAH}

Those who make a decision are sometimes in a situation to consider only one location, and then decision-making is reduced to accepting or rejecting the location. However, they are often in a
Collecting data on the possible actions directions of GAH is done by reconnaissance. Based on the acquired data, the selection of direction on which GAH will act is performed. The first following step in deciding is to formulate alternatives, then the ranking is performed - evaluation and rejection of those solutions that do not meet the defined criteria.

Using Delphy method, data collection and selection of criteria by which the selection of GAH routs of action is performed, are carried out (Božanić et al., 2011).

The first criterion $\left(\mathrm{K}_{1}\right)$ are "estimates related to the penetration of an opponent in a certain direction." Consideration of this criterion is done through two sub-criteria. The first sub-criterion is "the probability of penetration of an opponent in a certain direction" $\left(\mathrm{K}_{11}\right)$. Through the assessment of this sub-criterion we take into account whether it is a less protected direction, then the direction where is organized less antitank defence in the interstices, exposed side, the 
area adequate for performance of an air assault and the like. The second sub-criterion is the "impact that can be expressed over our units in the case of penetration of the enemy on the line" $\left(\mathrm{K}_{12}\right)$. Defining this sub-criterion includes consideration of the impact that any penetration of the enemy in that direction would have to the further outcome and course of operations (impact on the engagement of forces from the reserve, as well as other elements of the fighting schedule, estimates of our losses due to the such actions of the enemy, etc.), as well as to the action of GAH.

The second criterion $\left(\mathrm{K}_{2}\right)$ is the "impact that is achieved toward the opponents by closing a given direction." The first of two sub-criteria defining this criterion is the "degree of possibility of slowing the pace of opponents attack" $\left(\mathrm{K}_{21}\right)$, where would be evaluated the extent to which the activities of GAH could possibly slow the pace of attacking of an opponent in a given direction. Through the second sub-criterion, "possible losses of opponents in personnel and material technical means" $\left(\mathrm{K}_{22}\right)$, it is estimated the possible losses of an opponent which would follow as a consequence of the activities of GAH.

By the third criterion $\left(\mathrm{K}_{3}\right)$ are estimated "characteristics of directions". They are assessed through four sub-criteria. The first $\left(\mathrm{K}_{31}\right)$ is the "influence of soil properties on the organization of hindering." Very often the location where the operation is performed has a large impact on the manner of their execution. In this case, it may play an important role, and therefore it is estimated the way the land affects the operations of GAH. On spatial dimensions it will depend how many lines of hindering on a given direction will be organized, then if there is any possibility to avoid minefields, how effectively it is possible to set fire to protect the mine fields and other soil parameters that can affect the organization of hindering. The second sub-criterion $\left(\mathrm{K}_{32}\right)$ "time needed to prepare the hindering line on the direction" means a self-assessment of number and size of the minefields that would effectively shut the given direction, soil and other soil parameters that affect the speed of hindering line preparation. Through the third subcriterion $\left(\mathrm{K}_{33}\right)$ "time needed for taking the direction and executing the hindering" it would be estimated how quickly the GAH can get to the direction of hindering and hindering at particular direction in relation to the location of the initial position. The last sub-criterion $\left(\mathrm{K}_{34}\right)$ is the estimation of "negative influences of the direction hindering on the subsequent actions of our units." Within this sub-criterion it is estimated whether and to what extent the hindering of a certain direction can influence the subsequent actions of our units. Here we should consider the wider aspects such as the concept of the operation itself and possible assignments of units on the direction.

Mutual comparison of the two elements of the hierarchy (models) was performed using Saaty's scale and it is presented in Tables 4 to 7.

Table 4. The first level of criteria $\rightarrow$ first level of criteria

\begin{tabular}{rccc}
\hline & $\mathrm{K}_{1}$ & $\mathrm{~K}_{2}$ & $\mathrm{~K}_{3}$ \\
\hline $\mathrm{K}_{1}$ & - & $\tilde{3}$ & $\tilde{4}$ \\
$\mathrm{~K}_{2}$ & $\tilde{3}^{-1}$ & - & $\tilde{3}$ \\
$\mathrm{~K}_{3}$ & $\tilde{4}^{-1}$ & $\tilde{3}^{-1}$ & - \\
$\mathrm{I} . \mathrm{R}=0.00$ & & & \\
\hline
\end{tabular}


Table 5. Estimates related to the penetration of an opponent in the direction $\rightarrow$ Estimates related to the penetration of an opponent in the direction

\begin{tabular}{ccc}
\hline & $\mathrm{K}_{11}$ & $\mathrm{~K}_{12}$ \\
\hline $\mathrm{K}_{11}$ & - & $\tilde{2}$ \\
$\mathrm{~K}_{12}$ & $\tilde{2}^{-1}$ & - \\
\hline
\end{tabular}

Table 6. The impact on the opponent, which is achieved by closing direction $\rightarrow$ Impact on the opponent, which is achieved by closing direction

\begin{tabular}{rcc}
\hline & $\mathrm{K}_{21}$ & $\mathrm{~K}_{22}$ \\
\hline $\mathrm{K}_{21}$ & - & $\tilde{3}$ \\
$\mathrm{~K}_{22}$ & $\tilde{3}^{-1}$ & - \\
$\mathrm{I} . \mathrm{R}=0.02$ & & \\
\hline
\end{tabular}

Table 7. Characteristics of directions $\rightarrow$ Characteristics of directions

\begin{tabular}{rcccc}
\hline & $\mathrm{K}_{31}$ & $\mathrm{~K}_{32}$ & $\mathrm{~K}_{33}$ & $\mathrm{~K}_{34}$ \\
\hline $\mathrm{K}_{31}$ & - & $\tilde{1}$ & $\tilde{2}^{-1}$ & $\tilde{2}$ \\
$\mathrm{~K}_{32}$ & $\tilde{1}$ & - & $\tilde{3}^{-1}$ & $\tilde{2}$ \\
$\mathrm{~K}_{33}$ & $\tilde{2}$ & $\tilde{3}$ & - & $\tilde{3}$ \\
$\mathrm{~K}_{34}$ & $\tilde{2}^{-1}$ & $\tilde{2}^{-1}$ & $\tilde{3}^{-1}$ & - \\
$\mathrm{I} . \mathrm{R}=0.01$ & & & & \\
\hline
\end{tabular}

3.2.Analysis, synthesis and ranking of alternatives

In order to define the relative importance of criteria $\mathrm{K}_{1}-\mathrm{K}_{3}$ their comparison is done in pairs, according to the linguistic expressions which are given in Saaty's fuzzy scale (Table 2). Linguistic expressions that are used for comparison of criteria form the matrix $A$.

$$
\begin{aligned}
& K_{1} K_{2} \quad K_{3} \\
& A=\begin{array}{l}
K_{1} \\
K_{2} \\
K_{3}
\end{array}\left[\begin{array}{lll}
\tilde{1} & \tilde{3} & \tilde{4} \\
\tilde{3}^{-1} & \tilde{1} & \tilde{3} \\
\tilde{4}^{-1} & \tilde{3}^{-1} & \tilde{1}
\end{array}\right]
\end{aligned}
$$

All elements of the matrix are fuzzy numbers from Table 2. The elements that are on the main diagonal represent the fuzzy number $(1,1,1)$, while the matrix elements which are below the main diagonal are the reciprocal values of elements below the main diagonal.

In the next part of the paper a procedure of calculating the elements of AHP method (criteria and subcriteria and criteria function) will be presented for the degree of conviction of a decision maker $\beta=0.5$. For other values of the degree of conviction of decision makers there will be presented the final values of criteria functions for the given alternatives.

The weight vector $w$ of each of the criteria of the matrix $A$ is the sum of linguistic expressions that describe the criteria in the same row of the matrix $A$, which is divided by the sum of all the linguistic expressions that describe the criteria of the matrix $A$.

$$
\begin{aligned}
& w_{1}=\frac{\widetilde{1}+\widetilde{3}+\widetilde{4}}{\widetilde{1}+\widetilde{3}+\widetilde{4}+\widetilde{3}^{1}+\widetilde{1}+\widetilde{3}+\widetilde{4}^{-1}+\widetilde{3}^{-1}+\widetilde{1}}= \\
& =(0.101,0.359,0.985)
\end{aligned}
$$


166

$$
w=\left[\begin{array}{l}
w_{1} \\
w_{2} \\
w_{3}
\end{array}\right]=\left[\begin{array}{l}
(0.101,0.359,0.985) \\
(0.090,0.265,0.728) \\
(0.025,0.052,0.214)
\end{array}\right]
$$

In the next step, by using fuzzy there are defined the weights coefficients for comparisons in pairs, there are formed each of the gives sub-criteria. matrices of comparing the sub-criteria and

$$
\begin{aligned}
& A_{K_{1}}=\left[\begin{array}{cc}
\tilde{1} & \tilde{2} \\
\tilde{2}^{-1} & \tilde{1}
\end{array}\right] \Rightarrow w_{A_{K_{1}}}=\left[\begin{array}{l}
w_{11} \\
w_{12}
\end{array}\right]=\left[\begin{array}{l}
(0.073,0.226,0.662) \\
(0.030,0.104,0.294)
\end{array}\right] \\
& A_{K_{2}}=\left[\begin{array}{cc}
\tilde{1} & \tilde{3} \\
\tilde{3}^{-1} & \tilde{1}
\end{array}\right] \Rightarrow w_{A_{K 2}}=\left[\begin{array}{l}
w_{21} \\
w_{22}
\end{array}\right]=\left[\begin{array}{l}
(0.153,0.474,1.165) \\
(0.085,0.261,0.728)
\end{array}\right] \\
& A_{K_{3}}=\left[\begin{array}{cccc}
\tilde{1} & \tilde{1} & \tilde{2}^{-1} & \tilde{2} \\
\tilde{1} & \tilde{1} & \tilde{3}^{-1} & \tilde{2} \\
\tilde{2} & \tilde{3} & \tilde{1} & \tilde{3} \\
\tilde{2}^{-1} & \tilde{2}^{-1} & \tilde{3}^{-1} & \tilde{1}
\end{array}\right] \Rightarrow w_{A_{K 3}}=\left[\begin{array}{l}
w_{31} \\
w_{32} \\
w_{33} \\
w_{34}
\end{array}\right]=\left[\begin{array}{c}
(0.130,0.408,1.037) \\
(0.032,0.061,0.231) \\
(0.116,0.315,0.807) \\
(0.099,0.216,0.576)
\end{array}\right]
\end{aligned}
$$

Using fuzzy arithmetic and expressions:

$$
w_{j}=\left(\sum_{l=1}^{k} a_{i l} \cdot\left[\sum_{i=1}^{k j} \sum_{l=1}^{k j} a_{i l}\right]^{-1}\right) \cdot w_{j,} j=1, \ldots, M, p=1, \ldots, k_{j}
$$

where $w_{\mathrm{j}}$ is an aggregation of weight vector for sub-criterion.

Using the above expression we get the

$$
\begin{aligned}
w_{K_{1}}^{\prime}=w_{1} \cdot w_{K_{1}} & =\left[\begin{array}{l}
w_{1} \\
w_{1}
\end{array}\right] \cdot\left[\begin{array}{l}
w_{K_{11}} \\
w_{K_{12}}
\end{array}\right]=\left[\begin{array}{l}
(0.101,0.359,0.985) \cdot(0.073,0.226,0.662) \\
(0.101,0.359,0.985) \cdot(0.030,0.104,0.294)
\end{array}\right] \\
& =\left[\begin{array}{l}
(0.007,0.081,0.652) \\
(0.003,0.037,0.289)
\end{array}\right] \\
w_{K_{2}}^{\prime}=w_{2} \cdot w_{K_{2}} & =\left[\begin{array}{l}
w_{2} \\
w_{2}
\end{array}\right] \cdot\left[\begin{array}{l}
w_{K_{21}} \\
w_{K_{22}}
\end{array}\right]=\left[\begin{array}{l}
(0.090,0.265,0.728)[(0.153,0.474,1.165) \\
(0.090,0.265,0.728) \square(0.085,0.261,0.728)
\end{array}\right] \\
& =\left[\begin{array}{l}
(0.014,0.126,0.848) \\
(0.008,0.069,0.531)
\end{array}\right]
\end{aligned}
$$
the following: 


$$
\begin{aligned}
w_{K_{3}}^{\prime}=w_{3} \cdot w_{K_{3}} & =\left[\begin{array}{l}
w_{3} \\
w_{3} \\
w_{3} \\
w_{3}
\end{array}\right] \cdot\left[\begin{array}{l}
w_{K_{31}} \\
w_{K_{32}} \\
w_{K_{33}} \\
w_{K_{34}}
\end{array}\right]=\left[\begin{array}{c}
(0.025,0.052,0.214)(0.130,0.408,1.037) \\
(0.025,0.052,0.214)(0.032,0.061,0.231) \\
(0.025,0.052,0.214) \llbracket(0.116,0.315,0.807) \\
(0.025,0.052,0.214) \llbracket(0.099,0.216,0.576)
\end{array}\right] \\
& =\left[\begin{array}{l}
(0.0032,0.2121,0.2219) \\
(0,0008,0.0031,0.0494) \\
(0.0029,0.0163,0.1726) \\
(0.0024,0.0112,0.1232)
\end{array}\right]
\end{aligned}
$$

After completing the calculation of weight coefficients of criteria and subcriteria we get the final values of criteria functions for each of the studied alternatives.

$$
F=\left[\begin{array}{l}
F_{1} \\
F_{2} \\
F_{3} \\
F_{4}
\end{array}\right]=\left[\begin{array}{c}
(0.103,0.206,0.309) \\
(0.131,0.263,0.396) \\
(0.097,0.193,0.289) \\
(0.116,0.231,0.347)
\end{array}\right]
$$

To test the above model there were used illustrative data that describe the four possible directions of action of the additional hindering group. Characteristics of selected sites are described through the previously defined criteria.

In Table 8 it is shown the final ranking of the alternatives obtained by using fuzzy AHP method. Calculation of the elements in the table 8 was performed by using the expression (15).

$I_{T}^{\lambda}(A)=\left[\lambda a_{3}+a_{2}+(1-\lambda) a_{1}\right] \cdot 2^{-1}, \quad \lambda \in[0,1](15)$

In (15), $\lambda$ represents an optimism index which expresses the decision maker's attitude towards risk. A larger value of $\lambda$ indicates a higher degree of optimism. In practical applications, values $0,0.5$ and 1 are used respectively to represent the pessimistic, moderate and optimistic views of the decision maker. For given fuzzy numbers $A$ and $B$ it is said that if $I_{T}^{\lambda}(A)<I_{T}^{\lambda}(B)$, then $A<B$; if $I_{T}^{\lambda}(A)=I_{T}^{\lambda}(B$ then $A=B$; and if

\begin{tabular}{|c|c|c|c|c|}
\hline \multirow{2}{*}{$\begin{array}{l}\text { Alte- } \\
\text { rnative }\end{array}$} & \multicolumn{3}{|c|}{ Index of optimism } & \multirow{2}{*}{ 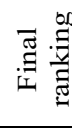 } \\
\hline & $\begin{array}{c}\lambda=0.0 \\
\text { (pessimistic) }\end{array}$ & $\begin{array}{c}\lambda=0.5 \\
\text { (moderate) }\end{array}$ & $\begin{array}{c}\lambda=1.0 \\
\text { (optimistic) }\end{array}$ & \\
\hline $\mathrm{A}_{1}$ & 0.205 & 0.212 & 0.220 & 4 \\
\hline $\mathrm{A}_{2}$ & 0.285 & 0.295 & 0.305 & 1 \\
\hline $\mathrm{A}_{3}$ & 0.210 & 0.220 & 0.230 & 3 \\
\hline $\mathrm{A}_{4}$ & 0.245 & 0.255 & 0.265 & 2 \\
\hline
\end{tabular}
$I_{T}^{\lambda}(A)>I_{T}^{\lambda}(B)$, then $A>B$.

Table 8. Final alternatives ranking

\section{CONCLUSION}

Fuzzification of AHP method leads to the conclusion that the values of the criteria functions change depending on the degree of conviction of the decision maker. Thus, with increasing the degree of conviction, the value of weighting coefficient of the observed criterion increases, while with reducing of the degree of conviction the value of weighting coefficient decreases.

By applying the method modified this way to the example of the choice of direction of GAH action it is led to the conclusion that the developed approach enables an optimal 
choice from a set of offered alternatives, so that the fuzzy AHP can be successfully used in the formulation of strategy of decision making process in this case. The presented model greatly reduces the stress of decision maker, but also allows people who have less experience to make optimal decisions.

The method concepted this way could be used in other examples of decision making especially when it comes to decision making where there are different degrees of conviction of decision makers.

\section{References}

Anagnostopoulos, K., Doukas, H., \& Psarras, J. (2008). Linguistic multicriterria analysis system combining fuzzy sets theory, ideal and anti-ideal points for location site selection. Experts System with Applications, 35, 2041-2048.

Arslan, T., \& Khisty, C.J.A. (2006). Rational approach to handling fuzzy perceptions in route choice. European Journal of Operational Research, 168 (2), 571-583.

Boender, C.G.E., De Graan, J.G., \& Lootsma, F.A. (1989). Multi-criteria decision analysis with fuzzy pairwise comparisons. Fuzzy Sets and Systems, 29 (2), 133-143.

Božanić, D., Pamučar, D., Đorović, B., Milić, A. \& Lukovac, V. (2011). Application of fuzzy AHP method on selection of actions direction of the Group for supplementary obstacle placing. In Proceedings of the 38th Symposium on operational research SYMOP-IS 2011, Zlatibor, Serbia, 556-559.

\title{
МОДИФИКАЦИЈА МЕТОДЕ АНАЛИТИЧКОГ ХИЈЕРАРХИЈСКОГ ПРОЦЕСА (АХП) ПРИМЕНОМ ФАЗИ ЛОГИКЕ: ФАЗИ АХП ПРИСТУП КАО ПОДРШКА ПРОЦЕСУ ДОНОШЕЊА ОДЛУКЕ О АНГАЖОВАЫУ ГРУПЕ ЗА ДОПУНСКО ЗАПРЕЧАВАЊЕ
}

\author{
Дарко Божанић, Драган Памучар и Драган Бојанић
}

\section{Извод}

У раду је приказана модификација АХП методе, која узима у обзир степен неизвесноси доносиоца одлуке, односно дозвољава да доносилац одлуке са одређеним степеном уверености (који је најчешће мањи од 100\%) дефинише који лингвистички израз одговара поређењу критеријума оптималности. За одређивање тежинских вредности критеријума и алтернатива коришћени су фази бројеви, као веома погодни за изражавање неодређености и неизвесности. На овај начин, након примене АХП методе, добијене су вредности критеријумских функција за сваку од посматраних алтернатива, којима одговара одређена вредност степена уверености. Тако је обезбеђено да се за различите вредности степена уверености може извршити генерисање различитих скупова вредности критеријумских функција. Постављени модел је тестиран на избору праваца дејства Групе за допунско запречавање, као поступку који је најчешће пропраћен већим или мањим степеном неодређености критеријума који су неопходни за доношење релевантне одлуке.

Кључне речи: Фази логика, фази АХП, АХП метода, Група за допунско запречавање, правац дејства. 
Božanić, D., Pamučar, D., \& Đorović, B. (2013). Modification of Analytic Hierarchy Process (AHP) method and its application in the defence decision making. TehnikaMandzment, 63, 327-334.

Božanić, D., \& Pamučar, D. (2010). Evaluating locations for river crossing using fuzzy logic. Military Technical Courier, 58 (1), 129-145.

Chang, W. (1981). Ranking of fuzzy utilities with triangular membership functio. International conference on policy analisys and information systems, 263-276.

Chang, Y.H., \& Yeh, C.H. (2012). A survey analysis of service quality for domestic airlines. European Journal of Operational Research, 149 (1), 166-177.

Chen, S.M., \& Tan, J.M. (2014). Handing multicriteria fuzzy decision-making problems based on vague set theory. Fuzzy Sets and Systems, 74, 163-72.

Chen, C.T. (2000). Extensions of the TOPSIS for group decision making problem under fuzzy environment. Fuzzy Sets and Systems, 114 (1), 1-9.

Chen, M.F., \& Tzeng, G.H. (2014). Combining grey relation and TOPSIS concepts for selecting an expatriate host country. Mathematical and Computer Modeling, 50 (13), 1473-1490.

Chen, S.M. (1997). A new method for tool steel materials selection under fuzzy environment. Fuzzy Sets and Systems, 92 (3), 265-274.

Chiadamrong, N. (2013). An integrated fuzzy multicriteria decision making under fuzzy environment. Computers and Industrial Engineering, 51 (1-2), 433-436.

Devetak, S., \& Terzić, M. (2011). Application of the analytic hierarchy process method in the selection of optimal tactical radio communication systems. Military Technical Courier, 59 (3), 161-176.
Ding, J.F., \& Liang, G.S. (2015). Using fuzzy MCDM to select partners of strategic alliances for liner shipping. Information Sciences, 183 (13), 197-225.

Dubois, D., \& Prade, H. (1978). Operation on fuzzy number. International Journal of Systems Science, 9, 613-626.

Dubois, D., \& Prade, H. (1987). The mean value of a fuzzy number. Fuzzy Sets and Systems, 24, 279-300.

Fan, Z.P., \& Liu, Y. (2015). A method for group decision-making based on multigranularity uncertain linguistic information. Experts System with Applications, 37, 4000-4008.

Gau, W.L., \& Buehrer, D.J. (2013). Vague sets. IEEE Transactions on Systems Manufacturing and Cybernetics, 23, 610-614.

Grzegrorzewski, P. (2013). The hamming distance between intuitionistic fuzzy sets. In Proceedings of the 10th IFSA world congress, Istanbul, Turkey, 35-38.

Heilpern, S. (1992). The expected value of a fuzzy number. Fuzzy Sets and Systems, 47 (1), 81-86.

Hong, D.H., \& Choi, C.H. (2014). Multicriteria fuzzy decision-making problems based on vague set theory. Fuzzy Sets and Systems, 128, 103-113.

Jae, M., \& Moon, J.H. (2002). Use of a fuzzy decision-making method in evaluating severe accident management strategies. Annals of Nuclear Energy, 29, 1597-1606.

Jantzen, J. (1998). Design of Fuzzy Controllers. Tech report. no 98-E 864. Technical University of Denmark, Department of Automation.

Kaufmann, A., \& Gupta, M. (1985). Introduktion to Fuzzy Arithmetic. Van Nostrand Reinhold Company, New York.

Kickert, W.J.M. (1978). Fuzzy theories on decision making: A critical review. Boston: 
Kluwer Academic Publishers.

Kujačić, M. (2001). Selection of the best options in designing the organization of postal traffic using the Analytic Network Process. Ph.D. Thesis. Belgrade: Faculty of Transport and Traffic Engineering, University of Belgrade.

Kuo, M.S., Tzeng, G.H., \& Huang, W.C. (2007). Group decision making based on concepts of ideal and anti-ideal points in a fuzzy environment. Mathematical and Computer Modelling, 45 (34), 324-339.

Laarhoven, P.J.M., \& Pedrycz, W. (2003). A fuzzy extension of Saaty's priority theory. Fuzzy Sets and Systems, 11, 229-241.

Li, R.J. (1999). Fuzzy method in group decision making. Computers and Mathematics with Applications, 38 (1), 91-101.

Liu, H.W., \& Wang, G.J. (2007). Multicriteria decision-making methods based on intuitionistic fuzzy sets. European Journal of Operational Research, 179, 220-233.

Lootsma, F.A. (1988). Numerical scaling of human judgment in pairwise-comparison methods for fuzzy multi-criteria decision analysis, Mathematical Models for Decision Support. NATO ASI Series F, Computer and System Sciences, Springer-Verlag, Berlin, Germany, 57-88.

Lootsma, F.A., Mensch, T.C.A., \& Vos, F.A. (1990). Multi-criteria analysis and budget reallocation in long-term research planning. European Journal of Operational Research, 47 (3), 293-305.

Ma, D., \& Zheng, X. (1991). 9/9-9/1 scale method of the AHP. Proceedings of the 2nd International Symposium on the AHP, Pittsburgh, 197-202.

Miller, G.A. (1956). The magical number seven plus or minus two: some limits on our capacity for processing information. Psychological Review, 63 (2), 81-97.
Military Lexicon. (1981). Military Paper Office. Belgrade.

Nehi, H.M. \& Maleki, H.R. (2005). Intuitionistic fuzzy numbers and it's applications in fuzzy optimization problem. In Proceedings of the 9th WSEAS International Conference on Systems, Athens, Greece.

Pamučar, D., Ćirović, G., \& Sekulović D. (2015). Development of an integrated transport system in distribution centres: A FA'WOT analysis. Tehnical gazette, 22 (3), accepted for publication.

Pamučar, D., Božanić, D., \& Đorović B. (2011a). Fuzzy logic in decision making process in the Armed forces of Serbia. Lambert Academic Publishing GmbH \& Co. KG, Germany.

Pamučar, D., Božanić, D., Đorović, B., \& Milić, A. (2011b). Modelling of the fuzzy logical system for offering support in making decisions within the engineering units of the Serbian army. International journal of the physical sciences, 6 (3), 592-609.

Pamučar, D., Ćirović, G., Sekulović, D., \& Ilić, A. (2011c). A new fuzzy mathematical model for multi criteria decision making: An application of fuzzy mathematical model in a SWOT analysis. Scientific Research and Essays, 6 (25), 5374-5386.

Pamučar, D., Đorović, B., Božanić, D., \& Ćirović, G. (2012). Modification of the dynamic scale of marks in analytic hierarchy process (AHP) and analytic network approach (ANP) through application of fuzzy approach. Scientific Research and Essays, 7 (1), 24-37.

Pamučar, D. (2010). Using fuzzy logic and neural networks during a decision making proces in transport. Military Technical Courier, 58 (3), 125-143.

Peneva, V., \& Popchev, I. (1998). 
Comparison of cluster from fuzzy numbers. Fuzzy Sets and Systems, 97 (1), 75-81.

Raju, K.S., \& Pillai, C.R.S. (1999). Multicriterion decision making in river basin planning and development. European Journal of Operational Research, 112 (2), 249-257.

Ray, T., \& Triantaphyllou, E. (1999). Procedures for the evaluation of conflicts in rankings of alternatives. Computers and Industrial Engineering, 1, 35-44.

Saaty, T.L. (1996). Analytic network process - decision making with dependece and feedback. RWS publications, Pittsburgh, PA.

Saaty, T.L. (1990). Multicriteria Decision Making - The Analytic Hierarchy Process. RWS Publications, Pittsburgh.

Saaty, T.L. (1980). The analytic hierarchy process. McGraw-Hill, New York.

Teodorović, D., \& Kikuchi, S. (1994). Fuzzy sets and applications in traffic and transport. Faculty of Transport and Traffic Engineering, University of Belgrade.

Triantaphyllou, E., \& Lin, C.T. (1996). Development and evaluation of five multiattribute decision making methods. International Journal of Approximate Reasoning, 14 (4), 281-310.

Triantaphyllou, E., Shu, B., Snachez, S.N., \& Ray, T. (1998). Multi-criteria decision making: An operations research approach. Encyclopedia of Electrical and Electronics Engineering, John-Njilley \& Sons, New York.

Wang, J.Q., \& Zhang, Z. (2014). Aggregation operators on intuitionistic trapezoidal fuzzy number and its application to multicriteria decision making problems. Journal of Systems Engineering and Electronics, 25 (2), 321-326.

$\mathrm{Xu}, \mathrm{Z}$., Shang, S., Qjan, W., \& Shu, W. (2010). A method for fuzzy risk analysis based on the new similarity of trapezoidal fuzzy numbers. Experts System with Applications, 37, 1920-1927.

Yager, R.R. (1978). Fuzzy decision making including unequal objectives. Fuzzy Sets and Systems, 1, 87-95.

Yager, R.R. (1988). On ordered weighted averaging aggregation operators in multicriteria decision making. IEEE Transactions on Systems Man and Cybernetics, 18, 183-190.

Ye, J. (2010). Improved method of multicriteria fuzzy decision-making based on vague sets. Computer-Aided Design, 39, 164-169.

Ye, J. (2014). Using an improved measure function of vague sets for multicriteria fuzzy decision making. Expert Systems With Applications, 37, 4706-4709.

Yeh, C.H., \& Deng, H. (2014). A practical approach to fuzzy utilities comparison in fuzzy multicriteria analysis. International Journal of Approximate Reasoning, 45 (2), 179-194.

Zadeh, L.A. (1965). Fuzzy sets. Information and Control, 8, 338-356.

Zhu, K.J., Jing, Y., \& Chang, D.Y. (1999). A discussion on extent analysis method and applications on fuzzy AHP. European Journal of Operational Research, 116 (18), 450-456.

Zimmermann, H.J. (1987). Fuzzy sets, decision making, and expert system. Boston: Kluwer Academic Publishers. 